\title{
Impact of Spiritual Intelligence on Perceived Stress among Male and Female University Students
}

\author{
G. Navya $\triangle 10$ and S. Sharma \\ Dept. of Human Development and Family Studies, Punjab Agricultural University, Ludhiana (141 001), India
}

Open Access

Corresponding $邓 \quad$ navya7897@gmail.com

0000-0002-6209-6322

ABSTRACT

$\mathrm{T}$

he present study was conducted in the year 2021 to assess the impact of spiritual intelligence on perceived stress among

male and female university students. The sample consisted of 160 youth aged between 23-24 years. Multi stage purposive random sampling was employed to draw sample from five constituent colleges of Punjab Agricultural University, Ludhiana who were equally distributed over the gender ( 80 males and 80 females). The objectives of the study were to assess and compare the level of spiritual intelligence and perceived stress in male and female university students. Spiritual intelligence questionnaire and stress scale were used as data collection tools to assess the spiritual intelligence and perceived stress of university students. The results revealed that spiritual intelligence was significantly high in female respondents against males and male respondents were found to have significantly greater perceived stress as compared to their female counterparts in all the dimensions namely pressure, physical stress, anxiety and frustration. Regression analysis proved that spiritual intelligence had negatively contributed to perceived stress revealing that with increase in spiritual intelligence, perceived stress was reduced in males and females significantly. The present study will be useful for the youth to understand the importance of spiritual intelligence and how it can impact on perceived stress. It would be also helpful for parents, counsellors, psychologists and human development professionals to understand the level of the stress among youth and thus can provide a better environment.

KEYWORDS: Gender, perceived stress, spiritual intelligence, university students

Citation (VANCOUVER): Navya and Sharma, Impact of Spiritual Intelligence on Perceived Stress among Male and Female University Students. International Journal of Bio-resource and Stress Management, 2022; 13(1), 62-68. HTTPS://DOI.ORG/10.23910/1.2022.2511a.

Copyright: (c) 2022 Navya and Sharma. This is an open access article that permits unrestricted use, distribution and reproduction in any medium after the author(s) and source are credited.

Data Availability Statement: Legal restrictions are imposed on the public sharing of raw data. However, authors have full right to transfer or share the data in raw form upon request subject to either meeting the conditions of the original consents and the original research study. Further, access of data needs to meet whether the user complies with the ethical and legal obligations as data controllers to allow for secondary use of the data outside of the original study.

Funding: The research was conducted with the kind support of Punjab Agricultural University.

Conflict of interests: The authors have declared that no conflict of interest exists.

RECEIVED on $12^{\text {th }}$ July 2021 RECEIVED in revised form on $25^{\text {th }}$ December 2021 ACCEPTED in final form on $21^{\text {st }}$ January 2022 PUBLISHED on $31^{\text {st }}$ January 2022 


\section{INTRODUCTION}

$\mathrm{T}$ he period of youth is one of the important phases of life, and is the symbol of vitality. If this phase is equipped with a deep sense of spirituality, the stress-free life of young people is guaranteed. The full spectrum of intelligence is made up of five dimensions namely physical intelligence, transcendental intelligence, intellectual intelligence, emotional intelligence and spiritual intelligence. Spiritual intelligence is one among the multiple intelligences that can evolve and rise on its own. Zohar and Marshall (2000) stated spiritual intelligence as "an intelligence that can position one's behaviours and experiences in a meaningful manner and through which one can resolve issues of immanent worth." The word spiritual got derived from the Latin word spiritus, which means "that gives life or vitality to a system".

While religiousness and spirituality are not related concepts, laypeople use them colloquially. Religion is an externally imposed set of beliefs and rules, while spirituality is the inner life of consciousness and its correlation with being in the universe (Oman, 2013). Spirituality has recently gained prominence as one of the most significant aspects of human life (Bagheri et al., 2011). People with high spiritual intelligence might accomplish meaningful and rewarding attributes by creating spirituality in their activities (Rostami and Hayedeh, 2014). Spiritual intelligence necessitates critical thinking and the construction of knowledge. Many traditions and parts of the psychological literature highlight the importance of acquiring meaning in spiritual development (Skrzypinska, 2014). According to recent findings, spiritual intelligence is the ultimate in human intelligence (Silingiene and Skeriene, 2015).

Stress is "the common denominator of all adaptive reactions in the body" and the events that produce stress are known as stressors (Selye, 1965). Perceived stress is a feeling of tension that is both biological and psychological. Perceived stress consists of positive stress and negative stress which are called "eustress" and "distress" respectively (Selye, 1974). It consists of feelings about the uncertainty and inconsistency of one's life, unpleasant issues and lack of confidence in one's ability to deal with problems or challenges. The word stress got derived from the Latin word stringer which means to draw tight. Stress is a state of mind-body association and is a component in disease manifestation that varies from person to person (McEwen, 2006). The situations that lead to stress are called stressors. The way people react and adapt to the stressors can be different even if the stressor is the same (McEwen and Wingfield, 2003).

Today's youth are immersed in an increasingly stressful environment. Modernization, cultural changes, social trends, and work pressure all lead to enhancing anxiety, depression, and chronic psychosocial stress in people (Liu et al., 2017). Job search is also a vital period that can cause stress, particularly for those who are unable to establish economic and psychological independence impacting university students (Lim, 2018). An individual who is adjusting to perceived stress will exhibit behavioural patterns. Brain is the key organ involved in perceiving and adjusting to social and physical stressors via various interacting mediators (McEwen et al., 2015). With increasing perceived stress, mortality rate tends to raise leading to greater number of deaths (Prior et al., 2016). When students are unable to meet or are in the process of meeting others' expectations, they experience anger, physical discomfort, violence, undesirable complexes, anxiety, and depression (Alam, 2010). High levels of perceived stress and anxiety could be reduced by preparing with the necessary coping and stress management abilities (Garboczy et al., 2021). Mascaro and Rosen (2006) found that as spiritual significance declines, the association between perceived stress and depression becomes stronger.

\section{MATERIALS AND METHODS}

$\mathrm{T}$ he study was conducted in the year 2021. Spiritual intelligence was determined through spiritual intelligence scale by Zainuddin and Ahmed (2010). It consists of 78 items which was divided into six dimensions namely inner self, inter self, biostoria, life perspectives, spiritual actualization and value orientation. Perceived stress was assesses using Lakshmi and Narain (2014) stress scale. This scale consists of 40 items and has the following four dimensions namely pressure, physical stress, anxiety and frustration.

\subsection{Study sites}

The study was undertaken in the Punjab Agricultural University, Ludhiana. The total sample was taken from the five constituent colleges of Punjab Agricultural University, Ludhiana namely i.e., College of Agriculture, College of Horticulture and Forestry, College of Agricultural Engineering \& Technology, College of Community Science and College of Basic Sciences \& Humanities.

\subsection{Method of data collection}

An online questionnaire was developed which consisted of questions from scales of spiritual intelligence and stress scale with the help of google forms to collect the data in view of the pandemic. The forms were sent to 250 postgraduate students from five constituent colleges of Punjab Agricultural University in order to get the desired data. Initially 230 forms were received out of which 160 students were selected having equal number of males and females.

\subsection{Statistical analysis}

The following statistical tools were used in order to analyse 
the data.

\subsubsection{Arithmetic Mean}

Arithmetic mean is acquired by summing up of all values acquired by males and females and further dividing total by the number of observations.

$\mathrm{A}=\frac{1}{\mathrm{n}} \sum_{\mathrm{i}_{=1}}^{\mathrm{n}} \mathrm{Xi}_{\mathrm{i}}$

$\mathrm{A}=$ arithmetic mean

$\mathrm{n}=$ number of items (e.g., the number of items or numbers being averaged)

$\mathrm{x}_{1}=$ the value of each individual item in the list of numbers being averaged

\subsubsection{Standard deviation}

Standard deviation is the deviation of the mean value in the complete sample from the number of individuals in a group. It was used to obtain the gender-wise mean scores of different dimensions of the variables. It has the below formula.

$\mathrm{S}=\mathrm{V} \frac{\sum(\mathrm{X}-\overline{\mathrm{X}})}{\mathrm{n}}$

Where,

$\mathrm{S}=$ Standard deviation

$\mathrm{X}=$ Individual observation

$\overline{\mathrm{X}}=$ Mean of $\mathrm{X}$

$\mathrm{n}=$ Number of items.

2.3.3. t-test

It was used to study the statistical differences in the mean scores of spiritual intelligence and perceived stress in male and female respondents. The following formula was used: $\mathrm{t}=\frac{\overline{\mathrm{X}}_{1}-\overline{\mathrm{X}}_{2}}{\mathrm{~s} \sqrt{\frac{1}{\mathrm{n}_{1}}+\frac{1}{\mathrm{n}_{2}}}}$

Where,

$\mathrm{X}_{1}=$ Mean score of group 1

$\mathrm{X}_{2}=$ Mean score of group 2

$\mathrm{n}_{1}=$ Number of subjects in group 1

$\mathrm{n}_{2}=$ Number of subjects in group 2

$\mathrm{S}=$ Standard deviation

$\mathrm{t}=$ Value of $\mathrm{t}$-statistic

Degree of freedom $=\left(\mathrm{n}_{1}+\mathrm{n}_{2}\right)-2$

2.3.4. Z-test

It was applied to determine the gender-wise differences across various dimensions of independent and dependent variable to observe significant differences. The formula used was:

$$
\mathrm{Z}=\frac{\mathrm{P}_{1}-\mathrm{P}_{2}}{\sqrt{\mathrm{PQ}}\left[\frac{1}{\mathrm{n}_{1}}+\frac{1}{\mathrm{n}_{2}}\right]}
$$

$\mathrm{P}=\frac{\mathrm{n}_{1} \mathrm{p}_{1}+\mathrm{n}_{2} \mathrm{p}_{2}}{\mathrm{n}_{1}+\mathrm{n}_{2}}$

Where,

$\mathrm{p}_{1}=$ Sample proportion of $1^{\text {st }}$ sample

$\mathrm{n}_{1}=$ Sample size of $1^{\text {st }}$ sample

$\mathrm{p}_{2}=$ Sample proportion of $2^{\text {nd }}$ sample

$\mathrm{n}_{2}=$ Sample size of $2^{\text {nd }}$ sample

$\mathrm{P}=$ Combined Proportion

$\mathrm{Q}=1-\mathrm{P}$

\subsubsection{Linear Regression Analysis}

Linear regression was applied to describe the gender-wise impact of spiritual intelligence on perceived stress. The variable (y) was described as the function of the independent variable $(\mathrm{x})$.

$[\mathrm{Y}=\mathrm{f}(\mathrm{X})]$

$\mathrm{Y}_{\mathrm{i}}=\mathrm{b}_{0}+\mathrm{b}_{1} \mathrm{X}_{\mathrm{i}}$

$\mathrm{b}_{1}=\frac{\mathrm{n} \sum \mathrm{XY}-\sum \mathrm{X} \sum \mathrm{Y}}{\mathrm{n} \sum \mathrm{X}^{2}-\left(\sum \mathrm{X}\right)^{2}}$

Where,

$b_{1}=$ Regression coefficient of $Y$ and $X$

$\mathrm{X}=$ Dependent variable

$\mathrm{Y}=$ Independent variable

$\mathrm{n}=$ No. of observation

\section{RESULTS AND DISCUSSION}

3.1. Gender wise mean scores $( \pm S D)$ of youth across different dimensions of spiritual intelligence

The Table 1 highlighted the gender wise mean scores of youth across different dimensions of spiritual intelligence. Mean score showed that overall spiritual intelligence was more in female respondents $(310 \pm 42.58)$ as compared to male respondents $291.74 \pm 56.45$. In the dimension of inner self, mean score was found to be high $(35.44 \pm 4.65)$ in female respondents as compared to the male respondents $33.7 \pm 6.18$ and mean score of inter self was more in females $(74.28 \pm 9.90)$ and in males it was $69.88 \pm 14.53$ concluding that females were least interested in expecting rewards while helping others. In female respondents, mean score of biostoria was more $(23.43 \pm 3.67)$ and in male respondents, low mean score $(21.26 \pm 5.42)$ was exhibited. While coming to another dimension of spiritual intelligence i.e., life perspectives, mean score of females was found to be high $(39.89 \pm 5.73)$ as compared to male respondents $(37.85 \pm 6.50)$ proving that females had better knowledge about origin and purpose of life. Female respondents exhibited better mean score $(86.50 \pm 15.59)$ as compared to males $(80.78 \pm 17.93)$ in 
Table 1: Gender wise mean scores $( \pm \mathrm{SD})$ of youth across different dimensions of spiritual intelligence $(n=160)$

\begin{tabular}{|c|c|c|c|c|c|}
\hline \multirow{2}{*}{$\begin{array}{l}\text { Dimensions } \\
\text { of Spiritual } \\
\text { Intelligence }\end{array}$} & \multicolumn{2}{|c|}{$\begin{array}{c}\text { Male } \\
(\mathrm{n} 1=80)\end{array}$} & \multicolumn{2}{|c|}{$\begin{array}{l}\text { Female } \\
\left(\mathrm{n}_{2}=80\right)\end{array}$} & \multirow[t]{2}{*}{ t-value } \\
\hline & Mean & $\pm \mathrm{SD}$ & Mean & $\pm \mathrm{SD}$ & \\
\hline $\begin{array}{l}\text { The inner } \\
\text { self }\end{array}$ & 33.70 & 6.18 & 35.44 & 4.65 & $2.010^{* * *}$ \\
\hline $\begin{array}{l}\text { The inter } \\
\text { self }\end{array}$ & 69.88 & 14.53 & 74.28 & 9.90 & $2.238^{* * *}$ \\
\hline Biostoria & 21.26 & 5.42 & 23.43 & 3.67 & $2.954^{\text {wat }}$ \\
\hline $\begin{array}{l}\text { Life } \\
\text { perspectives }\end{array}$ & 37.85 & 6.50 & 39.89 & 5.73 & $2.103^{* * *}$ \\
\hline $\begin{array}{l}\text { Spiritual } \\
\text { actualization }\end{array}$ & 80.78 & 17.93 & 86.50 & 15.59 & $2.155^{* * t}$ \\
\hline $\begin{array}{l}\text { Value } \\
\text { orientation }\end{array}$ & 48.28 & 10.16 & 50.48 & 8.30 & 1.499 \\
\hline $\begin{array}{l}\text { Overall } \\
\text { spiritual } \\
\text { Intelligence }\end{array}$ & 291.74 & 56.45 & 310.00 & 42.58 & $2.310^{* * *}$ \\
\hline
\end{tabular}

the dimension of spiritual actualization and when coming to last dimension of spiritual intelligence i.e., in value orientation, mean score was found to be more $(50.48 \pm 8.3)$ in female respondents as compared to males $(48.28 \pm 10.16)$ indicating that females were more aware of principles of right and wrong which were accepted by the society.

By the findings in the table 1, it was proved that spiritual intelligence was more in female respondents as compared to males with significance at one five cent level. The $\mathrm{t}$-value revealed differences to be significant in all the five dimensions of spiritual intelligence except in value orientation. Significant differences were found in inner self $(p<0.05)$, inter self $(p<0.05)$, biostoria $(p<0.01)$, life perspectives $(p<0.05)$, spiritual actualization $(p<0.05)$. Female respondents had more spiritual intelligence as they have better inner sense of wholeness, aware of meaning and purpose of life, have better assumption about their goals which have to be pursued in future.

3.2. Gender wise mean score $( \pm S D)$ differences of youth across different levels of spiritual intelligence

Gender wise mean score differences of youth across different levels of spiritual intelligence was showed in the table 2 . There were no gender wise significant differences found at high, average and low levels of spiritual intelligence. At high level of spiritual intelligence, female respondents (357.18 \pm 8.86$)$ had higher mean score as compared to male respondents $(354.75 \pm 14.12)$ whereas at average level of spiritual intelligence, mean score of female respondents
Table 2: Gender wise mean score $( \pm \mathrm{SD})$ differences of youth across different levels of spiritual intelligence $(\mathrm{n}=160)$

\begin{tabular}{lccccc}
\hline $\begin{array}{l}\text { Levels of } \\
\text { spiritual }\end{array}$ & \multicolumn{2}{c}{ Male $\left(\mathrm{n}_{1}=80\right)$} & \multicolumn{4}{c}{$\begin{array}{l}\text { Female } \\
\left(\mathrm{n}_{2}=80\right)\end{array}$} & Z-value \\
\cline { 2 - 5 } intelligence & Mean & $\pm \mathrm{SD}$ & Mean & $\pm \mathrm{SD}$ & \\
\cline { 2 - 5 } & 354.75 & 14.12 & 357.18 & 8.86 & 0.569 \\
High & 317.16 & 14.05 & 314.85 & 14.59 & 0.734 \\
Average & 234.33 & 49.55 & 249.71 & 44.51 & 1.059 \\
\hline
\end{tabular}

$(314.85 \pm 14.59)$ was found to be lower than male respondents $(317.16 \pm 14.05)$ and at low level, mean score of females $(249.71 \pm 44.51)$ was higher than males which was observed to be $234.33 \pm 49.55$.

\subsection{Gender wise mean scores $( \pm S D)$ of youth across different dimensions of perceived stress}

The Table 3 showed gender wise mean scores of youth across different dimensions of perceived stress. In male respondents, mean score of overall stress was more $(20.21 \pm 8.87)$ as compared to females $16 \pm 7.29$. Mean score was found to be high in males $(7.13 \pm 2.54)$ as compared to females $(5.61 \pm 2.39)$ in the dimension of pressure which showed that males were more worried about the expectations which need to be fulfilled in a given circumstance and when coming to physical stress, a dimension of perceived stress, high mean score was seen in male respondents $(2.56 \pm 1.30)$ as compared to mean score of females $1.91 \pm 1.15$. In males, mean score of anxiety was more $(6.60 \pm 3.62)$ and in females it was $(5.53 \pm 3.15)$ which showed that males were more likely to experience unpleasant emotional states psychologically

Table 3: Gender wise mean scores $( \pm \mathrm{SD})$ of youth across different dimensions of perceived stress $(n=160)$

\begin{tabular}{lccccc}
\hline $\begin{array}{l}\text { Dimensions } \\
\text { of perceived }\end{array}$ & \multicolumn{2}{c}{$\begin{array}{c}\text { Male } \\
\left(\mathrm{n}_{1}=80\right)\end{array}$} & \multicolumn{2}{c}{$\begin{array}{c}\text { Female } \\
\left(\mathrm{n}_{2}=80\right)\end{array}$} & Z-value \\
\cline { 2 - 5 } Stress & Mean & \pm SD & Mean & \pm SD & \\
\hline Pressure & 7.13 & 2.54 & 5.61 & 2.39 & $3.881^{* * * *}$ \\
Physical stress & 2.56 & 1.30 & 1.91 & 1.15 & $3.349^{* * *}$ \\
Anxiety & 6.60 & 3.62 & 5.53 & 3.15 & $2.00^{* * *}$ \\
Frustration & 3.93 & 2.66 & 2.95 & 2.21 & $2.52^{* * *}$ \\
Overall Stress & 20.21 & 8.87 & 16.00 & 7.29 & $3.28^{* * * *}$ \\
\hline$* * * p<0.001 ; * * p<0.01$ & & & &
\end{tabular}

and in the last dimension of perceived stress i.e., frustration, mean score revealed that frustration was more in males $(3.93 \pm 2.66)$ as compared to the female respondents, whose mean score was observed to be $2.95 \pm 2.21$.

To conclude, perceived stress was more in male respondents as compared to females with significance at one per cent 
level. The $\mathrm{t}$-value revealed differences to be significant in all the four dimensions of stress which were, pressure $(p<0.01)$, physical stress $(p<0.01)$, anxiety $(p<0.05)$ and frustration $(p<0.05)$.Perceived stress is more in males than female respondents because the coping strategies of males are not as effective as in females, also they do not seek help or share when they feel stress, they have not learnt to cope with stress efficiently and gets frustrated and irritated easily when a particular goal is not reached. Responsibilities to be fulfilled will be on males in most of the families and they participate more in the physical activities like sports and games which lead to more physical stress like headache and body pain and restlessness.

3.4. Gender wise mean score $( \pm \mathrm{SD})$ differences of youth across different dimensions of perceived stress

The Table 4 represented the gender wise mean score differences of youth across different levels of perceived stress. Significant difference $(\mathrm{p}<0.10)$ was found at high level of overall stress. Female respondents $(27.42 \pm 2.88)$ had lower mean score as compared to male respondents $(29.48 \pm 4.79)$ at high level of overall stress, when coming to moderate level of overall stress, mean score of female respondents $(18.49 \pm 3.02)$ was found to be higher than male respondents $(17.50 \pm 2.64)$ and mean score of females $(8.61 \pm 3.12)$ was higher than males $(8.41 \pm 1.77)$ at low level of overall stress.

\subsubsection{Pressure}

At high level of pressure, a dimension of perceived stress, female respondents $(8.89 \pm 1.05)$ had higher mean score as compared to male respondents $(8.85 \pm 1.53)$ whereas at moderate level of pressure, mean score of females $(5.36 \pm 1.11)$ was found to be higher than the mean score of male respondents was found to be $4.93 \pm 1.14$. Mean score of females $(2.44 \pm 0.73)$ was higher than males $(2.00 \pm 0.00)$ at low level of pressure and significant difference $(p<0.05)$ was observed at low level of pressure.

\subsubsection{Physical stress}

Significant difference $(p<0.10)$ was found at high level of physical stress. Low mean score was exhibited by female respondents as compared to males at high level of physical stress and at moderate level of physical stress mean score $(2.00 \pm 0.00)$ was found to be equal in both male and female respondents and mean score of females $(0.60 .0 .48)$ was lower than males $(0.74 \pm 0.44)$ at low level of physical stress.

\subsubsection{Anxiety}

Mean score revealed that at high level of anxiety, female respondents $(9.50 \pm 1.61)$ had higher mean score as compared to male respondents $(9.42 \pm 2.12)$ whereas at moderate level of anxiety, mean score of female respondents $(5.81 \pm 0.97)$
Table 4: Gender wise mean score $( \pm \mathrm{SD})$ differences of youth across different dimensions of perceived stress $(n=160)$

\begin{tabular}{|c|c|c|c|c|c|}
\hline \multirow{2}{*}{$\begin{array}{l}\text { Dimensions } \\
\text { of perceived } \\
\text { stress }\end{array}$} & \multicolumn{2}{|c|}{$\begin{array}{c}\text { Male } \\
\left(\mathrm{n}_{1}=80\right)\end{array}$} & \multicolumn{2}{|c|}{$\begin{array}{l}\text { Female } \\
\left(\mathrm{n}_{2}=80\right)\end{array}$} & \multirow[t]{2}{*}{ Z-value } \\
\hline & Mean & $\pm \mathrm{SD}$ & Mean & $\pm \mathrm{SD}$ & \\
\hline \multicolumn{6}{|c|}{ Pressure dimension } \\
\hline High & 8.85 & 1.53 & 8.89 & 1.05 & 0.133 \\
\hline Moderate & 4.93 & 1.14 & 5.36 & 1.11 & 1.585 \\
\hline Low & 2.00 & 0.00 & 2.44 & 0.73 & $2.406^{* * *}$ \\
\hline \multicolumn{6}{|c|}{ Physical stress dimension } \\
\hline High & 3.63 & 0.49 & 3.17 & 0.38 & $4.412^{\text {wat }}$ \\
\hline Moderate & 2.00 & 0.00 & 2.00 & 0.00 & NA \\
\hline Low & 0.75 & 0.44 & 0.68 & 0.48 & 0.554 \\
\hline \multicolumn{6}{|c|}{ Anxiety dimension } \\
\hline High & 9.42 & 2.12 & 9.50 & 1.61 & 0.169 \\
\hline Moderate & 5.13 & 0.83 & 5.81 & 0.97 & $2.531^{* *}$ \\
\hline Low & 2.09 & 0.92 & 1.61 & 1.16 & 1.550 \\
\hline \multicolumn{6}{|c|}{ Frustration dimension } \\
\hline High & 7.76 & 1.38 & 7.57 & 0.54 & 0.527 \\
\hline Moderate & 3.59 & 0.71 & 4.03 & 1.10 & $1.939^{*}$ \\
\hline Low & 1.33 & 0.68 & 1.11 & 0.80 & 1.239 \\
\hline \multicolumn{6}{|l|}{ Overall stress } \\
\hline High & 29.48 & 4.79 & 27.42 & 2.88 & $1.730^{*}$ \\
\hline Moderate & 17.50 & 2.64 & 18.49 & 3.02 & 1.447 \\
\hline Low & 8.41 & 1.77 & 8.61 & 3.12 & 0.285 \\
\hline
\end{tabular}

was found to be higher than male respondents $(5.13 \pm 0.83)$ and at low level of anxiety. mean score of females $(1.61 \pm 1.16)$ was lower than males $(2.09 \pm 0.92)$ and the data further revealed, differences to be significant $(p<0.05)$ at moderate level of anxiety.

\subsubsection{Frustration}

In the dimension of frustration, female respondents $(7.57 \pm 0.54)$ had lower mean score as compared to male respondents $(7.76 \pm 1.38)$ whereas at moderate level of frustration mean score of female respondents $(4.03 \pm 1.10)$ was found to be higher than male respondents $(3.59 \pm 0.71)$. At low level of frustration, significant difference $(p<0.01)$ was found and mean score of females $(1.11 \pm 0.80)$ was lower than males, whose mean score was found to be $1.33 \pm 0.68$.

3.5. Gender-wise differences on impact of spiritual intelligence on perceived stress among youth

Gender-wise differences on impact of spiritual intelligence 
on perceived stress among youth which was analysed using linear regression which was presented in the Table 5. In male respondents, the coefficient of determination ( $\mathrm{R}$ square) showed that $84 \%$ variation of perceived stress was explained by spiritual intelligence and on the other hand in females, the coefficient of determination $\left(\mathrm{R}^{2}\right)$ showed that $81 \%$ of variation of stress was explained by spiritual intelligence. It was found that spiritual intelligence had contributed to perceived stress in males $(\beta=-0.23)$ and female respondents ( $\beta=-0.29)$ negatively and the gender-wise differences were found to be significant $p<0.01$.

Table 5: Gender-wise differences on impact of spiritual intelligence on perceived stress among youth $(n=160)$

\begin{tabular}{|c|c|c|c|c|}
\hline $\begin{array}{l}\text { Male } \\
\text { (n1=80) }\end{array}$ & Co-efficient & $\begin{array}{l}\text { Std. } \\
\text { Err. }\end{array}$ & t-value & $\mathrm{p}$-value \\
\hline $\begin{array}{l}\text { Intercept/ } \\
\text { Constant }\end{array}$ & 4.810 & 4.260 & 1.129 & 0.26 \\
\hline $\begin{array}{l}\text { Spiritual } \\
\text { intelligence }\end{array}$ & -0.23 & 0.014 & $20.306^{\text {nate }}$ & $7.12 \mathrm{E}-33$ \\
\hline $\mathrm{R}^{2}$ & \multicolumn{4}{|c|}{0.84} \\
\hline $\begin{array}{l}\text { Female } \\
\left(\mathrm{n}_{2}=80\right)\end{array}$ & Co-efficient & $\begin{array}{l}\text { Std. } \\
\text { Err. }\end{array}$ & $\mathrm{t}$-value & $\mathrm{p}$-value \\
\hline $\begin{array}{l}\text { Intercept/ } \\
\text { Constant }\end{array}$ & 22.128 & 4.482 & 4.937 & $4.40 \mathrm{E}-06$ \\
\hline $\begin{array}{l}\text { Spiritual } \\
\text { intelligence }\end{array}$ & -0.29 & 0.015 & $15.946^{\text {tow }}$ & $2.91 \mathrm{E}-26$ \\
\hline $\mathrm{R}^{2}$ & 0.76 & & & \\
\hline $\mathrm{n}$ & \multicolumn{4}{|c|}{160} \\
\hline
\end{tabular}

\section{CONCLUSION}

Zemales had more spiritual intelligence and less perceived - stress than males with significance at five \% level and one $\%$ level respectively. It was further found that spiritual intelligence had negatively contributed to perceived stress proving that with increase in spiritual intelligence, perceived stress is reduced among male and female respondents.

\section{REFERENCES}

Alam, M.M., 2010. Effect of emotional intelligence and academic stress on academic success among adolescents. Journal of Community Guidance and Research 27(1), 53-61.

Bagheri, F., Akbarizadeh, F., Hatami, H., 2011. The relationship between nurses' spiritual intelligence and demographic characteristics. Journal of South Medical 4(4), 256-263.
Garboczy, S., Szeman-Nagy, A., Ahmad, M.S., Harsanyi, S., Ocsenas, D., Rekenyi, V., Al-Tammemi, A.B., Kolozsvari, L.R., 2021. Health anxiety, perceived stress, and coping styles in the shadow of the COVID-19. Journal of BioMed central Psychology 9(1), 53-56.

Lakshmi, V., Narain, S., 2014. Stress coping techniques scale. National Psychological Corporation, Agra, India. https://npcindia.com/

Lim, A.Y., Lee, S.H., Jeon, Y., Yoo, R., Jung, H.Y., 2018. Job-seeking stress, mental health problems, and the role of perceived social support in university graduates in Korea. Journal of Korean Medical Science 33(19), 149-151.

Liu, M.N., Li, N., William, A.L., Khan, H., 2017. Association between psychosocial stress and hypertension: a systematic review and meta-analysis. Journal of Neurological Research 39(6), 573-580.

Mascaro, N., Rosen, D.H., 2006. The role of existential meaning as a buffer against stress. Journal of Humanistic Psychology 46(2), 168-90.

McEwen, B.S., 2006. Protective and damaging effects of stress mediators: central role of the brain. Journal of Dialogues clinical Neuroscience 8(4), 367-381.

McEwen, B., Bowles., N., Gray, J., 2015. Mechanisms of stress in the brain. Journal of Nature Neuroscience 18(10), 1353-1363.

McEwen, B.S., Wingfield, J.C., 2003. The concept of allostasis in biology and biomedicine. Journal of Hormone Behaviour 43(1), 2-15.

Oman, D., 2013. Defining religion and spirituality. In: Paloutzian, R.F., Park, C.L. (Eds.), Handbook of the psychology of religion and spirituality. Guilford Press, New York, 23-47. https://www.researchgate. net/publication/275276795_Defining_Religion_and_ Spirituality

Prior, A., Frenger-Gron, M., Larsen, K.K., Larsen, F.B., Robinson, K.M., Nielsen, M.G., Christensen, K.S., Mercer, S.W., Vestergaard, M., 2016. The association between perceived stress and mortality with multimorbidity. American Journal of Epidemiology 184(3), 199-210.

Rostami, A.M., Hayedeh, C.G., 2014. Prediction of marital satisfaction based on spiritual intelligence. Journal of Procedia Social and Behavioural Sciences 116(21), 2573-2577.

Selye, H., 1965. The stress syndrome. Journal of American Nursing 65(3), 97-99.

Selye, H., 1974. Stress without distress. Journal of Bruxelles Medicine 56(2), 205-210. 
Silingiene, V., Skeriene, S., 2015. Expression of leaders' spiritual intelligence in a context of service organizations: A gender approach. Journal of ProcediaSocial and Behavioural Sciences 213, 758-763.

Skrzypinska, K., 2014. The threefold nature of spirituality in the inclusive cognitive framework. Archive for the Psychology of Religion 36(3), 277-302.

Zainuddin, R., Ahmed, A., 2011. Rouqan spiritual intelligence scale. National Psychological Corporation, Agra, India. https://www.scribd.com/ document/137190484/National-Psychological-Corp Zohar, D., Marshall, I., 2000. Spiritual intelligence: The Ultimate Intelligence. Pp. 3-18. Bloomsbury Press, New York. 